\title{
栄養と運動に関する実験的研究 \\ Experimental Studies on the Interrelationships of Nutrition and Physical Exercise
}

1. ビタミン $\mathrm{E} の$ 運動持久能におよぼす効果について Effects of Prolonged Administration of Vitamin E on Running and Swimming Performances of Young Adult Rats. (Report 1)

\author{
国立栄養研究所 (National Institute of Nutrition) \\ 太田冨貴雄 (Fukio Ohta) 辻悦 子 (Etsuko Tsuji) \\ 恩田京子 (Kyoko Onda) 鈴木 秀 雄 (Hideo Suzuki) \\ 鈴木 慎次 郎 (Shinjiro Suzuki)
}

A long term experiment was conducted to evaluate the ergogenic effects of vitamin $\mathrm{E}$ and/or linoleic acid on the athletic performance of sedentary and exercising rats.

Male albino rats, weighing approximately $80 \mathrm{~g}$, were divided into four dietary groups and fed one of these diets containing $20 \%$ of either beef tallow or safflower oil with and without supplementation of additional vitamin $\mathrm{E}(330 \mathrm{mg} / \mathrm{kg}$ diet). Safflower oil was employed to provide linoleic acid to the diet.

Ten rats from each dietary group were housed in conventional small cages and served as sedentary controls; another ten animals were allowed voluntary exercise in large individual activity cages equipped with a revolving wheel inside.

During the period of 2 months on the experimental regimen, the urines of five rats from each group were collected at the ages of 45, 60 and 70 days for the assay of hydroxyproline which could be regarded as the endogenous indicator of growth and development.

At the end of the experimental period, five rats from each group were sacrficed, and the antioxidant status was estimated from both the degrees of resistance of erythrocytes to hemolysis by dialuric acid and the amounts of peroxidation products of liver lipids (TBA value). The other five rats were forced to run to exhaustion at $5^{\circ}$ incline on a motor driven treadmill (average speed of 16 meters per $\min$ ). The survived rats were again forced to swim to exhaustion with a load equivalent to $2 \%$ of body weight in $32^{\circ} \mathrm{C}$ water, provided 10 days later they proved to have recovered from the preceding treadmill program as judged by their weight gains.

A small but significant temporary increase of urinary hydroxyproline excretion was found in almost all rats at the age of 60 days in comparison with 45 and 70 days, suggesting that even in rats the turnover rate of collagen was accelerated with the impetus of growth at adolescence as seen in human beings. Vitamin $\mathrm{E}$ and exercise did not exert further effects on endogenous collagen metabolism.

Decreased resistance of erythrocytes to hemolysis by dialuric acid was observed in the rats fed on the tallow diet without additional vitamin $\mathrm{E}$, but there was no evidence of vitamin $\mathrm{E}$ deficiency in the animals fed on the safflower oil diet. Voluntary excercise did not promote the onset of vitamin E deficient symptoms.

The rats, revoluting a wheel 500 to 1500 times daily throughout the experimental period, ran over 3 -fold longer than the sedentary controls. 
Both vitamin $\mathrm{E}$ and linoleic acid resulted a small increase in the running capacity of the exercising rats, but these substances failed to prolong the running endurance time of the sedentary controls. Simultaneous administration of vitamin $\mathrm{E}$ and linoleic acid did not enhance the ergogenic effects of either vitamin $\mathrm{E}$ or linoleic acid given separately.

No definite trends were found in swimming performance among the rats under different experimental conditions.

\section{は じめ に}

米国では20年前からビタミン $\mathrm{E}$ や麦肧芽油の抗疲労效果が注目を集めるようになり，運動持久力を強めて 競技成績の向上をはかるためスポーツ選手などに使用されるようになった。

ビタミンEを多量に含む小麦肧芽油の抗疲労効果は, イリノイ大学体力研究所でスポーツ選手や一般人を被 検者に詳しく調べられ，小麦肧芽油には運動時の循環機能を強め持久力を堌強する明らかな効果があると結論 された(12)3)。佐藤(4) はビタミン含量を変えた 3 種の飼料で白ねずみを40日間飼育した後遊疥試験を行ない，ビ タミン $\mathrm{E}$ 欠乏群で遊泳時間が低下し，1日20 $\mathrm{mg}$ の大量投与で著明に遊泳時間をひき延したことからビタミン E は運動持久力を強めるのに有効であると考皇た。Curto ${ }^{5)}$ は更に, ビタミン Eを与えた蛙で, 筋収縮にとも なら疲労の発現が遅れることをみ,ビタミン Eの抗疲労効果を証拠だてた。これに対し, Consolazio ら ${ }^{6)}$ は小 麦肧芽油，ビタミン $\mathrm{E}$ と 5 週間白ねずみに連続投与したが遊泳時の耐久力を強める効果がみられなかったと 述べ，Sharman7) る水泳訓練中の少年に 1 日 $400 \mathrm{mg}$ のビタミン E 6 週間与えたが，循環機能や運動能力に 何ら好影響を拉よぽさなかったと報告している。

ビタミン $\mathrm{E}$ の体力強化作用について上述の上うに諸家の成績が一致しない原因が, ビタミン $\mathrm{E}$ 投与量, 体力 検査法, 動物の種類，ビタミンE投与時期など諸種の実験条件の違いに基づく場合もあると思われる。事実， 小麦胚芽油は訓練中のスポーツ選手の体力強化には有効であったが, 普段運動量の少ない一般成人の体力向上 にはあまり效果がなかったといった報告2)やモルモットの遊泳時間を昆ばすのに小麦肧芽油は卓効があった が，白ねずみの運動能には殆ど影響しなかったとする実験例8)などは，その好例といえよう。

今回の実駼は自由に運動させた白ねずみと運動を制限した白ねずみに, 長時間ビタミン Eを単独または大量 のリノール酸と同時に与光た後, 体力試験を課してビタミン $\mathrm{E}$ の抗疲学, 体力強化作用を確かめるとともに大 量のリノール酸ないし普段の運動がピタミン $\mathrm{E} の$ 效力発現にいかに影響するかを検討して，スポーツ選手の強 化に役立て上うとして行なったものである。

\section{実 験 方 法}

生後40日, 体重 $80 \mathrm{~g}$ の Wistar 系白ねずみを10匹むて8群に分け, うち4 群は安静群とし運動量を少なくす るため狭少な籠で飼育した。残る 4 群は運動群とし内部に周囲 $1 \mathrm{~m}$ の水車を取りつけた広い籠に入れ, 自由に 運動させた。運動籠の水車軸はカウンターに連結され，水車の回転数，即ちねずみの運動量（走行距離）が䛨 み取れるようになっている。

安静, 運動各 4 群には第 1 表に示す組成の実験食を与えた。実験食は 1 ) ビタミン Eは十分量含むがリノ 一ル酸は少ない，2）ビタミン E, リノール酸とも少ない，3）ビタミン E, リノール酸ともに多量に含む，

4 ）ビタミン E少なくリノール酸は多いの 4 種類で，各群には原則として朝 10 時から夕刻 5 時までの 7 時間 に限り自由に提食させた。時間を限って食慨を与えたのは, 運動群の活動量を增し運動効果をはっきり出すた 
めと，採尿を都合よく運ぶためである。

ビタミン $\mathrm{E}$ は飼料 $1 \mathrm{~kg}$ 当り $330 \mathrm{mg}$ 補足し, リノール酸の補給 には構成脂肪酸の $70 \%$ 以上をリール酸が占めるサフラワー油を 牛脂にかえて使用した。

実験食は60日間投与し, その間体重, 攝食量, 運動量を適時記 録した。白ねずみが生後45日，60日，70日に達した時，各実験群 から特定の 5 匹を選び，各時期 2 日間ずつ尿を集めた。採集した 尿は $50 \mathrm{~m} l$ に減圧濃縮した後, ハイドロキシプロリン量をProckop の方法9) で定量し，成長の内因性指標とした。

60 日の実験飼有期間が終わった後, 各群半数のねす゚み（5 匹） を 1 夜絶食させ, 体重 $100 \mathrm{~g}$ 当り $5 \mathrm{mg}$ のネンプタールを注射して 麻酔をかけ，心蔵から血液を採った。採血後直ちに肝臓も摘出し， 一定量を過酸化物洒 (TBA值) ${ }^{10)}$ の測定に供した。血液は生理食 塩水中で遠心分離を行なって血球を集め, ジアール酸による溶血

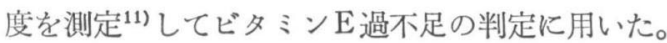

各実験群の残り 5 匹でトレッドミル走行ないし水泳による体力 試験を行ない, ビタミン $\mathrm{E}$ の体力増強勃果を検討した。トレッド ミルの条件は勾配 $5^{\circ}$, 速度は時間の節約をはかるため 2 時間未满 は $16 \mathrm{~m} /$ 分， 2 時間から 5 時間まで $21 \mathrm{~m} /$ 分， 5 時間を超えて走り 続けた場合は 1 分間 $28 \mathrm{~m}$ と時間が長くなるほど速くした。な特, 各ねずみとも体力試験に入る前に 1 日 5 〜 10 分， 5 日間トレッド ミル上を走らせ,トレッドミルに慣れるように配虑した。

トレッドミル試験を終えたねずみは，前と同じ条件で更に10日 間飼育を続けて体力の回復をはかった後, 水温 $32^{\circ} \mathrm{C}$, 水深 $45 \mathrm{~cm}$ の水槽中に入れ，遊泳耐久力の検定を行なった。ねずみには体重 の $2 \%$ 相当の重りを負荷し, 浮上が困難になるまでの時間を測定 した。

\section{実 験 結 果}

i ) 発育, 掑食量, 運動量

第 1 図に55日の実験期間中の体重增加量, 提食量, 運動量が, 各群 1 匹当りの総和として示されている。この図からビタミン $\mathrm{E}$ やリノール酸の大量摂取は成長に殆ど影響を与えないことがわか

Table 1. Composition of diets

\begin{tabular}{lc}
\hline & $\begin{array}{c}\text { High fat diet } \\
\%\end{array}$ \\
\hline$\alpha$-Starch & 24 \\
Dextrin & 24 \\
Casein & 25 \\
$*$ Fat & 20 \\
Salt mix. & 4 \\
Fiber & 2 \\
Vitamin mix. & 0.85 \\
Cholin-Cl & 0.15 \\
\hline
\end{tabular}

* Beef tallow or safflower oil

Note 1) $5000 \mathrm{IU}$ of V.A \& $12.5 \mu \mathrm{g}$ of V. $\mathrm{D}_{2}$ per $\mathrm{kg}$ of diet

2) One kilogram of the basal diet was supplemented with $330 \mathrm{mg}$ of $\alpha$-tocopherol acetate for vitamin $\mathrm{E}$ therapy.

Fig. 1 Effects of additional vitamin $\mathrm{E}$ and linoleic acid on growth, food intake and physical activity of growing rats. (cummulative figures for 55 days)

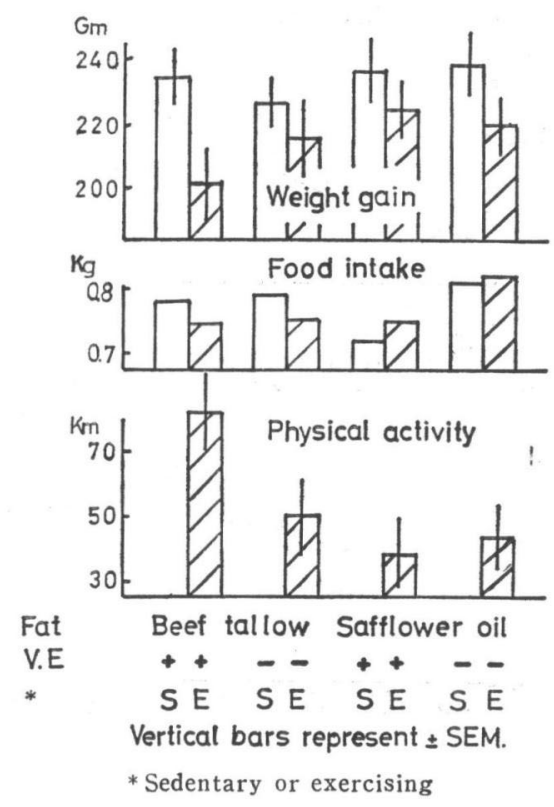

る。各運動群の発育は実験中期まで安静群と差がなかったが, 後期から運動の影響が現われ始め, 全体重增加 量は安静群に打よばなかった。

摂食量は初期の 1 日 $10 \mathrm{~g}$ から中期・後期には15〜17 $\mathrm{g}$ に増加したが, ビタミン Eやリノール酸含量に左右さ れることはなかった。 
運動群の活動量はビタミンEだけを補足されたねずみで最も多く平均 1 日 $1500 \mathrm{~m}$ を走ったことになり,リ， 一ル酸を大量に摂った群では 1 日600〜 $800 \mathrm{~m}$ と運動量が半減した。ただし，これは大量のリノール酸に運動量 を低下させる作用があるというより，個体差または籠の設置場所などの条件の違いが重なったためと思われる。 ビタミンEの過量搨取によっては, 普段の活動量は殆ど影響されなかった。

1 日 $500 \mathrm{~m}$ 水車を回した群（ビタミン $\mathrm{E}$, リノール酸とも添加）で安静対照群より提食量が多いにもかかわ らず, 体重增は安静群に劣ることからみて, 白ねずみが 1 日 $500 \mathrm{~m}$ 自由に走れば生理, 代謝面に何らかの運動 効果が現われると思われる。

ii）ハイドロキシプロリン排泄量

尿中ハイドロキシプロリン排泄量は人間の場合, 成長がスパートする思春期に一畤的に增加することが知ら れている ${ }^{12)}$ これは骨の伸長にともない骨コラーゲンの分解も六進するためと思われるが，白ねずみにも同様 の傾向がみられるか, 更に運動, ビタミン E, リノール酸の大量拱取などにより排泄量が影響されるか否かを 確かめるため, 実験期間中ねす゚みが45日齢，60日齢，70日龄に達した時採尿しハイドロキシプロリン排泄量の 測定を行なった。

結果は第 2 図に示すよ5, ねずみに特いて子生後 60 日近くに明らかに一過性のハイドロキシプロリン排泄が

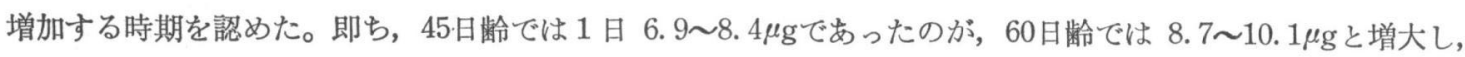

Fig. 2 Time cource of urinary hydroxyproline excretion in growing rats.
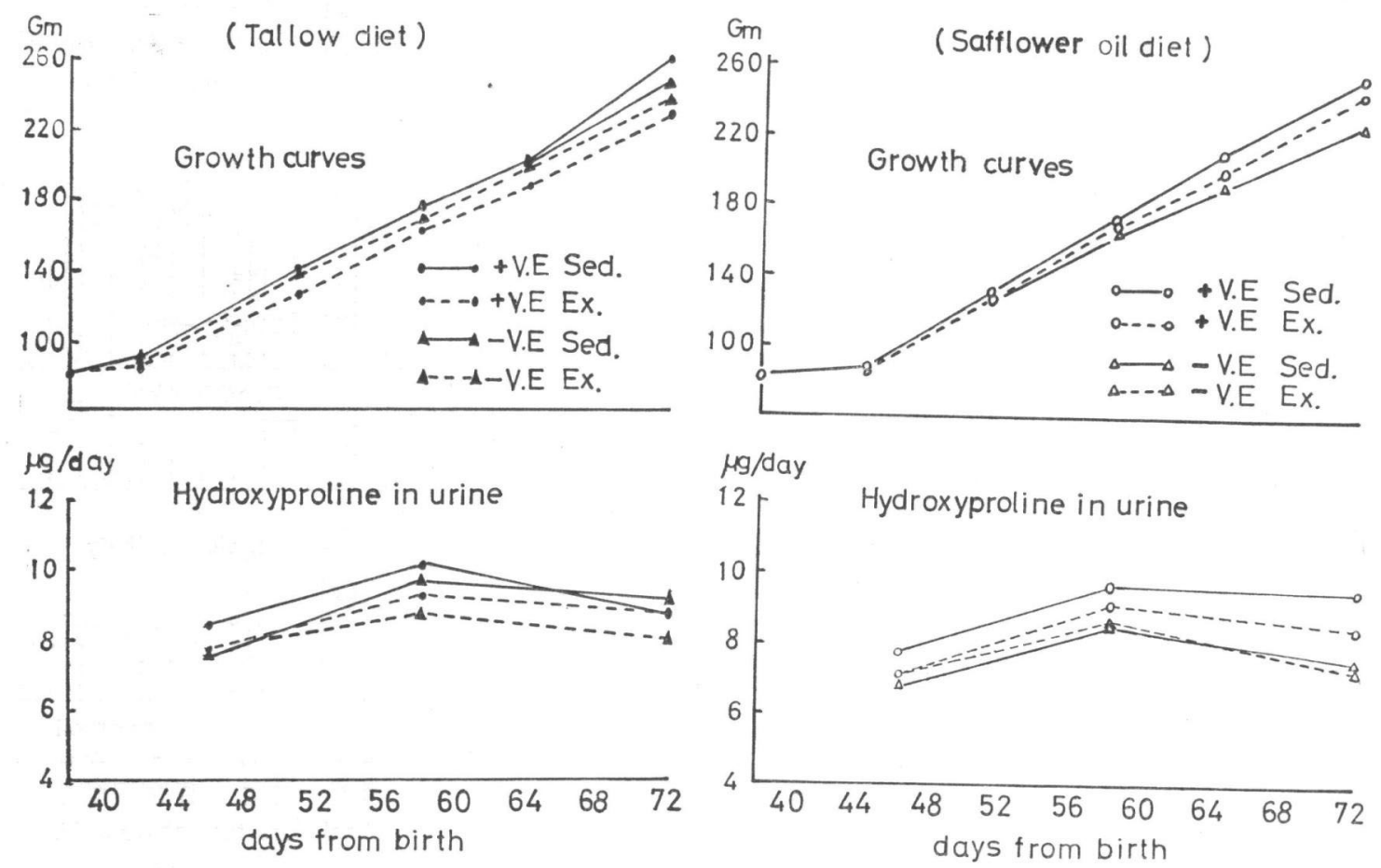

70 日譮には $7.3 \sim 9.6 \mu \mathrm{g}$ と次第に減少する傾向が明らかであった。第 2 表には生後 60 日目のハイドロキシプ ロリン排泄量（体重 $100 \mathrm{~g}$ 当り）をもとに，運動，ビタミン $\mathrm{E}$, リノール酸の多量摂取のコラーゲン代謝に括 よぼす影響をまとめてあるが, 運動と安静, ビタミン E補足の有無, リノール酸摂取の多少などの実験因子間 で，いずれの場合も有意差は認められなかった。 
iii) 臟器重量

採血に供した各群ねずみの解剖時臟器重量を体重 $100 \mathrm{~g}$ 当 りに直して第 3 表に掲け゚てある。

心臓は体重 $100 \mathrm{~g}$ 当り $0.3 \sim 0.35 \mathrm{~g}$ と実験群間で羛がなく 肝臓と腓腹筋は運動により幾分肥大する傾向がみられたが, 統計的な有意差は認め難かった。

腹部の脂肪沈着量は運動量多く体重の少ないビタミン $\mathrm{E}$ 添 加低リノール酸食の運動ねずみで有意に減少した他は群間に

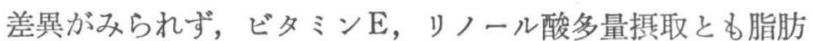
沈着を䂆方する効果は認められなかった。

副腎は運動群が18〜 18.8mg と安静群の $13.3 \mathrm{mg}$ に比べて 有意に大きく，随意な運動によっても副腎の機能に何らかの 影響を受けることがはっきりした。リノール酸多量摂取によ
Table 2. Comparison of urinary hydroxyproline levels among the rats at the age of 60 days under different experimental conditions

$\begin{array}{ll}\text { Experimental groups } & \begin{array}{l}\text { Hydroxyproline } \\ \text { in urine } \mu \mathrm{g} / \mathrm{day} /\end{array} \\ 100 \mathrm{~g} \text { body wt. }\end{array}$

1.
Sedentary
$5.93 \pm 0.13^{*}$
5. $75 \pm 0.16$

Exercising

2.

V.E supplement $\quad 6.00 \pm 0.13$

Non supplement $\quad 5.68 \pm 0.15$

3.

Linoleic acid supplement $\quad 5.79 \pm 0.15$ Non supplement $\quad 5.90 \pm 0.14$

$*$ mean $\pm \mathrm{SEM}$.

Table 3. Effects of voluntary exercise and additional vitamin $\mathrm{E}$ on the weight of liver, heart, muscles and adrenals of young adult rats (per $100 \mathrm{~g}$ body weight)

\begin{tabular}{|c|c|c|c|c|c|c|c|c|}
\hline \multicolumn{3}{|c|}{ Experimental groups } & \multirow{2}{*}{$\begin{array}{c}\text { Final } \\
\text { body wt. } \\
\text { (g) }\end{array}$} & \multirow{2}{*}{$\begin{array}{l}\text { Liver } \\
(\mathrm{g})\end{array}$} & \multirow{2}{*}{$\begin{array}{l}\text { Heart } \\
(\mathrm{g})\end{array}$} & \multirow{2}{*}{$\begin{array}{c}\text { Muscles* } \\
\text { (g) }\end{array}$} & \multirow{2}{*}{$\begin{array}{l}\text { Fat pads** } \\
\text { (g) }\end{array}$} & \multirow{2}{*}{$\begin{array}{c}\text { Adrenals } \\
\text { (mg) }\end{array}$} \\
\hline Fat & $\begin{array}{l}\text { edentary or } \\
\text { xercising }\end{array}$ & V.E & & & & & & \\
\hline \multirow{4}{*}{$\begin{array}{l}\text { Beef } \\
\text { Tallow }\end{array}$} & Sed. & + & 322 & 3. 40 & 0.32 & 0.54 & 3.32 & 14.4 \\
\hline & Ex. & + & 280 & 3. 75 & 0.32 & 0.61 & 1. 70 & 18.7 \\
\hline & Sed. & - & 311 & 3. 28 & 0.30 & 0.56 & 2.90 & 13.3 \\
\hline & Ex. & - & 291 & 3. 76 & 0.33 & 0.59 & 2.50 & 18.8 \\
\hline \multirow{4}{*}{$\begin{array}{l}\text { Safflower } \\
\text { oil }\end{array}$} & Sed. & + & 314 & 3.28 & 0.31 & 0.56 & 2.59 & 15.2 \\
\hline & Ex. & + & 312 & 3. 61 & 0.33 & 0.58 & 2.78 & 18.0 \\
\hline & Sed. & - & 316 & 3. 26 & 0.33 & 0.58 & 2.60 & 16. 2 \\
\hline & Ex. & - & 300 & 3.41 & 0.35 & 0.61 & 2.17 & 18.5 \\
\hline
\end{tabular}

* Gastrocnemius muscles ** perirenal fat pads.

っても幾分副腎の肥大が認められた。ただし，運動とリノール酸多量摂取の組合わせが副腎の肥大を強調する ことはなく,ビタミン Eは副腎に何ら影響を与えなかった。

iv）ビタミンEの過不足状態

実験飼育終了後の各群白ねずみのピタミン $\mathrm{E}$ 過不足の状熊を, ジアール酸に対する溶血抵抗性と肝臓脂質の 過酸化物量 (TBA值) から確かめた（第 3 図）。

溶血反応からみてピタミン $\mathrm{E}$ 欠の兆候が現われたのは, ピタミン $\mathrm{E}$ 無添加の牛脂摄食群 (リノール酸寡少) に限られ, 運動, 安静群ともとの程度に差がなく正常の $25 \%$ と大幅に溶血抵抗力の低下が認められた。ビタミ ンEの必要量を高めるリノール酸を多量に摂取した白ねずみでビタミンE欠乏の症状が現われなかったのは， リノール酸を供給するために使用したサフラワー油中にビタミンEがかなり含まれていたためと思われる。ち なみにサフラワー油は $100 \mathrm{~g}$ 中にビタミン $\mathrm{E} 80 \mathrm{mg}$ 含むのに対して，牛脂ではわずか $1 \mathrm{mg}$ と極めて少ないこ とが示されている13)。

肝臓の過酸化物量はピタミンEを添加しない群で添加群と比べて有意の増加が認められたが，運動負荷，リ 
Fig. 3 Effects of voluntary exercise and experimental diets on the antioxidant status of the young adult rats.
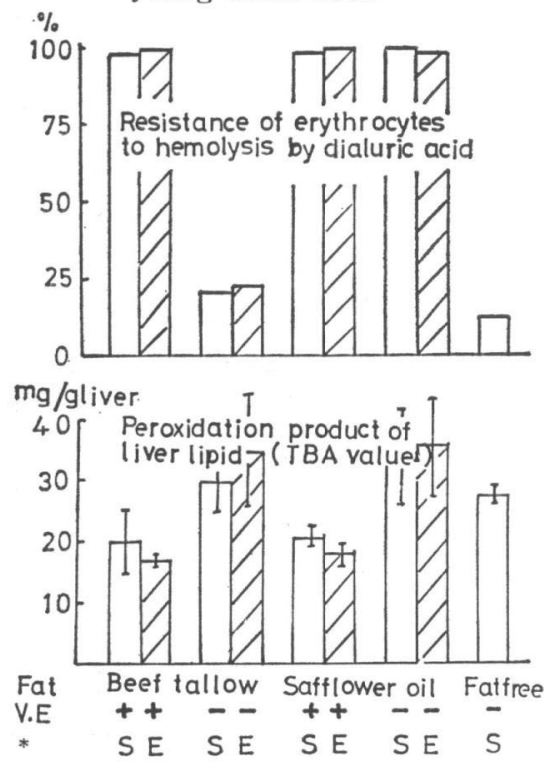

Vertical bars represent \pm SEM.

* Sedentary or exercising

Table 5. Comparison of running performance among the rats under different experimental conditions

\begin{tabular}{lc}
\hline \multicolumn{1}{c}{ Treatment } & $\begin{array}{c}\text { Distance } \\
\mathrm{km}\end{array}$ \\
\hline 1. Sedentary & $0.98 \pm 0.08^{*}$ \\
Exercising & $3.11 \pm 0.40$
\end{tabular}

2. Sedentary

1) V.E supplement $\quad 0.98 \pm 0.12$

Non supplement $\quad 0.97 \pm 0.14$

2) Linoleic acid supplement $\quad 0.98 \pm 0.08$

Non supplement $\quad 0.97 \pm 0.16$

3. Exercising

$\begin{array}{ll}\text { 1) V.E supplement } & 3.49 \pm 0.58\end{array}$

Non supplement $\quad 2.74 \pm 0.58$

2) Linoleic acid supplement $\quad 3.46 \pm 0.63$

$\begin{array}{ll}\text { Non supplement } & 2.77 \pm 0.53\end{array}$

* mean \pm SEM.
Table 4. Comparison of the amounts of peroxidation products of liver lipid among the rats under different experimental conditions

\begin{tabular}{|c|c|}
\hline $\begin{array}{l}\text { Experimental } \\
\text { groups }\end{array}$ & $\begin{array}{l}\text { TBA value } \\
\mathrm{mg} / \mathrm{g} \text { liver }\end{array}$ \\
\hline \multicolumn{2}{|l|}{ 1. * } \\
\hline Sedentary & $31.8 \pm 4.0^{* *}$ \\
\hline Exercising & $35.3 \pm 5.7$ \\
\hline \multicolumn{2}{|l|}{2.} \\
\hline V.E supplement & $19.2 \pm 1.4$ \\
\hline Non supplement & $33.5 \pm 3.4$ \\
\hline \multicolumn{2}{|l|}{ 3. $*$} \\
\hline Linoleic acid supplement & $32.4 \pm 4.6$ \\
\hline Non supplement & $34.7 \pm 5.3$ \\
\hline
\end{tabular}

Fig. 4 Effects of additional vitamin $\mathrm{E}$ and linoleic acid on running performance of sedentary and exercising rats.

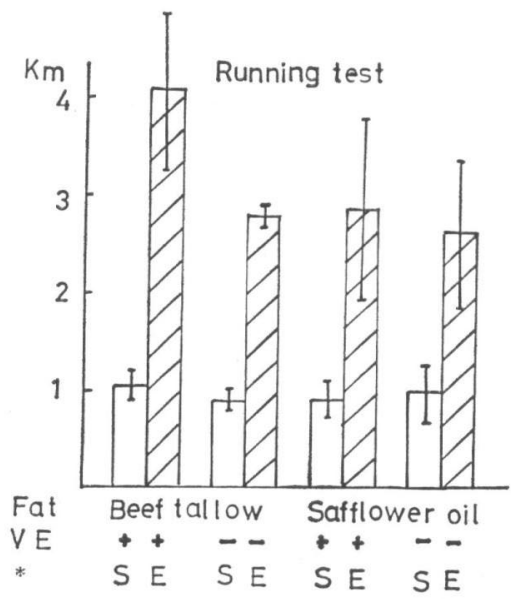

Rats were forced to run to exhaustion up $5^{\circ}$ incline at average treadmill Speed of $16 \mathrm{~m} / \mathrm{min}$.

Vertical bars represent \pm SEM.

* Sedentary or exercising

ノール酸の摂食量には関係しなかった（第 4 表）。

v）体力試験

トレッドミル強制走行試験の成績は, ビタミン $\mathrm{E}$ 添加低リノール酸食の運動群が平均 $4 \mathrm{~km}$ を走り抜き他群 を圧倒した。ビタミン $\mathrm{E}$ ，リノール酸とも十分な運動ねす゚みは平均 $2.9 \mathrm{~km}$ を走ったに過ぎず，ビタミン $\mathrm{E} 欠$

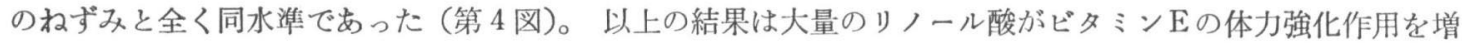

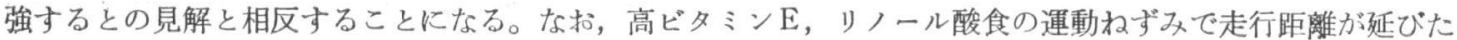




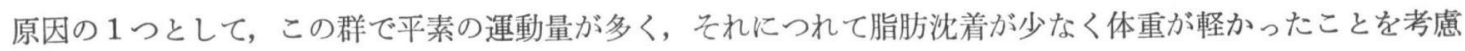
する必要があろう。

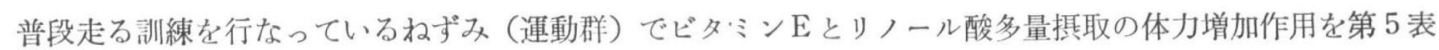

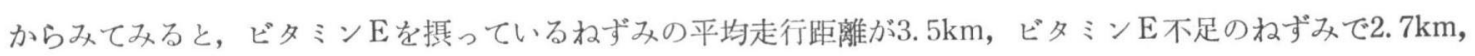
リノール酸摂取の多いねす゚みが $3.5 \mathrm{~km}$, 少ない悋ずみで $2.8 \mathrm{~km}$ とピタミン $\mathrm{E}$, リノール酸とも効力が認め られたが，個体間で成績にバラつきがあり有意差は表われなかった。

Fig. 5 Effects of additional vitamin $\mathrm{E}$ and linoleic acid on swi. mming performance of sede$\min$ ntary and exercising rats.

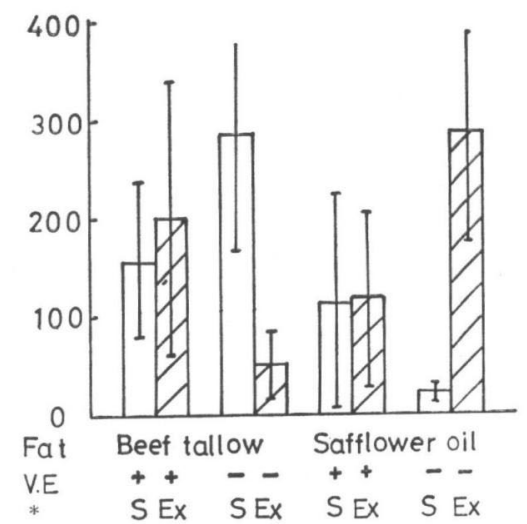

Rats were forced to swim to exhaustion in $35 c$ water with a weight equivalent to $2 \%$ of body weight attached to the tail of each rat.

Vertical bars represent \pm SEM

* Sedentary or exercising
Table 6. Comparison of swimming performance among the rats under different experimental conditions

\begin{tabular}{lc}
\hline Treatment & Swimming time \\
\hline 1. Sedentary & $140.4 \pm 41.3^{*}$ \\
Exercising & $186.8 \pm 44.1$
\end{tabular}

2. Sedentary

1) V.E supplement $\quad 139.9 \pm 58.2$ Non supplement $\quad 140.9 \pm 65.8$

2) Linoleic acid supplement $\quad 64.7 \pm 45.2$ Non supplement $\quad 216.1 \pm 64.0$

3. Exercising

1) V.E supplement $\quad 159.8 \pm 69.4$ Non supplement $\quad 210.0 \pm 64.9$

2) Linoleic acid
Supplement

Non supplement $\quad 154.2 \pm 62.7$

* mean \pm SEM.

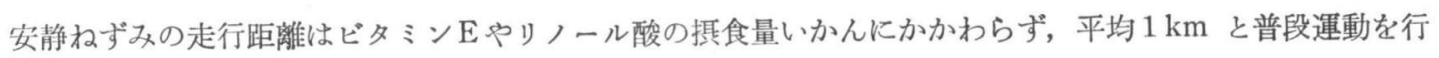
なっているねす゚みに比ぺてはるかに短く, 水車の回転による自由運動ねずみで訓練効果が体力面にはっきり現 われることが確かめられた（第 5 表）。

遊泳試験の各実験群の成績は第 5 図に示した通りである。耐久時間の長かったのはピタミン E, リノール酸 とも少ない安静群とビタミン $\mathrm{E}$ 不足のリノール酸の多い運動群で, 共に 5 時間近くの遊泳に耐えた。これに対 し遊泳時間の短かったのは, ピタミン $\mathrm{E}$, リノール酸の少ない運動群と, ビタミン $\mathrm{E}$ 不足, リノール酸摂取の 多い安静群で50分以下であった。以上のことからわかるように各実験群の成績に実験条件による一定の傾向が 認められず，各群の成績は白ねずみの個体差によると考えた方が納得のゆく結果になった。

運動ねずみの遊泳時間は平均 187 分に対して安静ねす゚みでは 140 分と傾向的には普段の運動訓練の成果が現

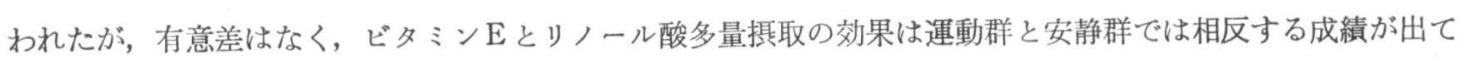
両者の効力の有無を断定することは困難であった（第 6 表）。

\section{考察}

雄ねす゚みのビタミン $\mathrm{E}$ 要求量は成長と生殖作用を指標にとれば 1 日 $1 \mathrm{mg}$ 以下といわれている ${ }^{14)}$ 。今回の実 験では 1 日 $5 \mathrm{mg}$ 程度のピタミンEを白ねずみに与えて, 運動体力の強化にピタミン $\mathrm{E} か ゙$ 効果があるか否かを 
判断しょうと試みた。この量は人間での実験例が多く $1 \mathrm{~g}$ 以下で効果をみていることに鑑み，体重から比例的 に求めたものである。ただし白ねずみでの既存の実験例では佐藤 ${ }^{4)} か ゙ 1$ 日 $20 \mathrm{mg}$ でビタミン $\mathrm{E}$ の効力劣認め, Consolaziob) は $37 \mathrm{mg}$ と極めて大量投与したにるかかわらずビタミンEの効果には否定的な結論を出している などビタミン Eの使用量は今回よりはるかに多い。今回の実験でリノール酸を多量摂取した場合の体力增強作 用も併せて観察したが，これは Cureton 2)の実験で小麦胚芽油の効果はビタミン E単独の効力に優り, 他に有 效成分が存在する可能性が示唆され，かつこれが必須脂肪酸であろうとする見解が示されているからである。 なお Ershoff ${ }^{8)}$ は棉実油投与モルモットで固型飼料投与群をはるかに凌ぐ水泳耐久力を観察していることも上 述の見解を裏付けると思われた。

今回の実験ではビタミンEを平素運動しているねずみと運動を制限したねずみに与えて，ビタミンEの体力 強化作用の検討を行なった。結果は運動制限ねずみに対してビタミン E は体力試験の成績を高めるのに全く効 果を示さなかったが, 普段走っているねずみの走行持久力を增強するのに, 平均值からみてのことであるが幾 分効果が認められた。前述のように今回のピタミン E 使用量は 1 日 $5 \mathrm{mg}$ と少なかったが, 佐藤年 の例のよう に1 日20mg 前後と量をふやせば明膫な効果が期待されょう。以上の結果は Cureton ${ }^{2)}$ の人の実驗でみられた 傾向とよく一致することから，ピタミン Eの効果があるとすれば，訓練中は運動に対する適応性を高めるか， あるいは酸素補給が制限となるような長時間にわたる運動時にその持久力を強める場合の 2 つ可能性が考光 られ，今後一層の検討が要望される。

リノール酸多量摂取の運動に対する効果は, 単独投与時の訓練ねす゚みに限って幾分好影響を与えたようたが, ビタミンEと併用した時にはビタミン Eの効果を更に強める働きは認められなかった。

小麦胚芽油の体力強化作用はピタミン E 単独に優るとされているが ${ }^{12)}$, 大量のリノール酸との協同効果は 否定され，他の有効成分の検索は今後の課題となった。

白ねずみの体力をみるのに今回はトレッドミル走行試験と遊泳試験を併用したが, 走力試験では安静群が 1 $\mathrm{km}$ 前後, 運動群が $3 \mathrm{~km}$, 運動訓練の効果がはっきり現われ, かつ, 同一飼育条件間に極めて類似した成績 が得られたことから白ねす゚みの体力をみるのに比較的適した方法に思える。これに対し遊泳試験の成績はきわ めて個体差が大きく, 実験条件による一定の傾向が認められないなど体力をみるのは走力試験より劣る結果と なった。この原因として遊泳試験の水温は $25^{\circ} \mathrm{C}$ 近辺といわれているが16), 今回は冬期に実験を行なったので 水温を $32^{\circ} \mathrm{C}$ と幾分高くしたこと, 更に遊泳時間は体重に比例するとの報告 ${ }^{17)}$ を勘案して各ねずみに体重の 2 \%相当の重りをつけたが，この負荷量が適当でなかった場合など考觉られる。

ピタミン $\mathrm{E}$ の々々白ねずみの成長阻害を起こすことは以前から知られているが18)1920), 今回は久乏兆候が 現われたのはビタミン $\mathrm{E}$ 無添加の牛脂使用群に限られ，かつこの群の成長も殆ど他群と差がなかったことから， 未だ完全なビタミンE欠乏の状態達しえなかったものと思われる。サフラワー油でビタミンE欠乏の兆候が 全く現われなかったのは原料油脂中に $100 \mathrm{~g}$ 当り $80 \mathrm{mg}$ と大量のビタミン れる。

運動がビタミン $\mathrm{E}$ 要求量を飛躍的に高めるとすれば, ビタミン $\mathrm{E}$ 無添加の運動群より強いビタミン $\mathrm{E}$ 欠乏 状態に達すると期待されたが, 結果は全く安静群と変わらず，このことを立証することはできなかった。

尿中ハイドロキシプロリン排泄量は人間の場合, 成長のスパート期に一時的に增大することが知られている が，今回の実験で白ねずみも60日齢近辺に一時的にハイドロキシプロリン排泄の增大を認め, 人間と同様ねず みも成長のスパートにともなってハイドロキシプロリン排泄が増すことがわかった。な扮我々の実験で長骨を 


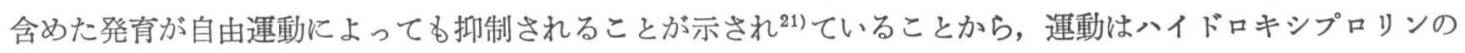
排泄量に何らかの影響を与えると期待されたが，今回の実験ではこれを明らかにすることができなかった。

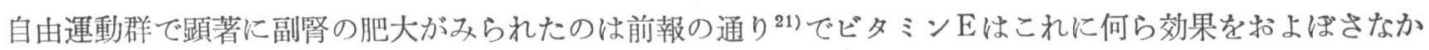
った。

\section{要 約}

1）生後 40 日の白ねずみを安静群と運動群に分け，前者は運動を制限し，後者には自由に水車を回す運動を させながら,ビタミンEないし多量のリノール酸を単独または同時に60日間投与し, 最後にトレット゚ミル走行

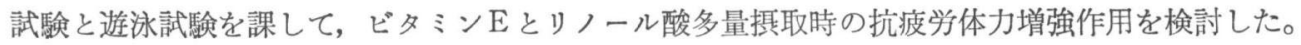

2）トレッドミル試験で運動群は安静群の倍の距離を走り, 平素の訓練の成果が体力試験の成績によく反映 された。

3）ビタミン Eとリノール酸の多量摂取は運動群の走行距離を幾分のばす傾向がみられたが，統計的有意差 は認められなかった。

ただし，ピタミン Eと多量のリノール酸の併用は各単独投与の場合と成績に差がなく, 小麦胚芽油の強い効 力の一半が大量のリノール酸摂取にめるとの考光は否定された。

遊泳試験の成績は個体間のバラつきが大きく群間で実験条件による一定の傾向が認められなかった。

4）運動ねずみで副腎の肥大が顕著であったがビタミン E, 大量のリノール酸摄取ともこの傾向に何ら影響 を与壳なかった。

5） ハイドロキシプロリンの尿中排泄量は雄ねずみの性的成熟が始まる60日龄近辺で一時的に增加すること が認められ，白ねずみでも人間と同様の思春前期に一過性に骨コラーゲンの代謝立進があると思われる。 ただし，ハイドロキシプロリン排泄に，運動，ピタミン E,リノール酸多量摂取の影響はみられなかった。

6）ビタミン $\mathrm{E}$ 無添加の牛脂投与群にのみビタミン $\mathrm{E}$ 欠の兆候が認められた。ただ平素の運動がビタミン $\mathrm{E}$ 欠の発現を促がすとの証拋は兄られなかった。

$$
\text { 文献 }
$$

1) Cureton, T. K.: Science News Letter, 66, 216 (1954)

2) Cureton, T. K.: Am. J. Physiol., 179, 628 (1954)

3) Cureton, T. K. et al.: Research Quart., 26, 391 (1955)

4) 佐藤伝 : 体力科学, 11, 151 (1962)

5 ) Curto, G. M.: Zootec. Net., 12, 203 (1957) (Nutr. Abst. Rev., 27, 4817, 1957)

6) Consolazio, C. F. et al.: J. Appl. Physiol., 19, 265 (1964)

7) Sharman, I. M. et al.: Proc. Nutr. Soc. 29, 36A (1970)

$8)$ Ershoff, B. B. et al.: Federation proc., 14, 431 (1955)

9) Prockop, D. J.: Anal. Biochem., 1, 228 (1960)

10) Tarnadgis, B. G. et al.: J. Sci. Food Agric., 15, 602 (1964)

11) Friedman, L. et al.: J. Nutrition, 65, 143 (1958)

12) 長嶺晋吉他: 国立栄養研究所研究報告, 昭和 $42-43$ 年度, 3 頁

13）久野寧他編 : ビタミン学, 金原出版, 212頁 (1956)

14) Evans, H. M.: Am. J. Physiol., 126, 487 (1937)

15) Cureton, T. K.: 東京オリンピック選手強化対策本部第一回コーチ会議特別講演 (1960)

16) 杉崎速雄 : 防衛衛生, 12, 403 (1965)

17) Lee, M. et al : J. Nutrition, 84, 136 (1964)

18) Blumberg, H.: J. Biol. Chem., 108, 227 (1935)

19) Martin, G. J.: J. Nutrition, 13, 679 (1937)

20) Ringsted, A.: Biochem, J., 29, 788 (1935)

21）鈴木慎次郎他：Ann. Report Nat. Inst. Nutrition, Tokyo 1 (1967) 